\title{
Possible use of phosphohexose isomerase as a preliminary to exfoliative cytology in screening for cervical carcinoma ${ }^{1}$
}

\author{
GRAINGER G. MUIR \\ From the Department of Clinical Biochemistry, Luton and Dunstable and \\ Bedford General Hospitals
}

SYNOPSIS The activities of phosphohexose isomerase and 6-phosphogluconate dehydrogenase have been studied in the vaginal fluid of women from the gynaecological departments. Women from these departments gave a very high false positive rate, though no cases of carcinoma in situ were not detected by estimating phosphohexose isomerase levels. It gave considerably better results int malignancy than 6-phosphogluconate dehydrogenase. It is suggested that the use of phosphohexose isomerase might be of value in screening well women during a mass cytology programme.

The success of exfoliative cytology in the diagnosis of carcinoma of the cervix has highlighted the possibility of eliminating this disease by a mass screening programme. It is agreed that a mass survey based on exfoliative cytology presents many financial and technical disadvantages.

Failure of the assays of the vaginal fluid content of beta glucuronidase (Kasdon, Homburger, Yorshis, and Fishman, 1953; Fishman, Green, Homburger, Kasdon, Nieburgs, McInnis, and Pund, 1954) and 6-phosphogluconate dehydrogenase (Bonham and Gibbs, 1962) to provide a basis for a mass screening programme has been a disappointment. Levels of both these enzymes have been raised in women with benign disease or have not been elevated in cases of carcinoma in situ or invasive carcinoma (Lawson, 1959; Muir, Canti, and Williams, 1964; Bell and Egerton, 1965; Lawson and Watkins, 1965). The majority of workers have been regarding enzymology as a means of replacing exfoliative cytology rather than an adjunct to it. In a mass screening programme an ability to sort out reliably those cases which might have carcinoma in situ from those which have not carcinoma in situ would relieve the cytologist of a considerable burden. The lower the number of false positive results the better, but it is more essential that no cases of carcinoma in situ be missed. The fact that the test is not a specific test for

${ }^{1}$ This work is part of an M.D. thesis submitted to the University of London.

Received for publication 21 March 1966 carcinoma is unimportant; provided that it measure a reaction of the cervical and vaginal epithelium to abnormalities, amongst these abnormalities woulä be carcinoma.

Another major requirement of any mass screening technique is that it should be robust and easy to assay. Evidence in this paper suggests that the glycolytic enzyme, phosphohexose isomerase, wi fill all these requirements.

Phosphohexose isomerase has been widely studie in clinical conditions. Its main use has been in the assessment of carcinoma of the breast. Bodansky in 1954 followed up cases of carcinoma of the breast and found that serial estimations of the serum phosphohexose isomerase activity gave the best guide to the patient's short-term prognosis. Joplit and Jegatheesan (1962) and Jegatheesan and Joplin (1962) confirmed Bodansky's work and found that the enzyme was by far the most reliable of the serum enzymes in prognosis. Jegatheesan (1959) and Muk and Fawcett (1965) found that carcinomatoufs human mammary tissue had elevated enzyme levefs as compared with normal breast tissue. Weber anf Cantero (1957), in a study of a variety of hepatoma found that in Norikoff hepatoma the phosphohexose isomerase content was raised. Morris (1963) showed that in Morris hepatoma 5123-D and 7800, phosphoo hexose isomerase was not increased, but its level wa? not as depressed as were some of the other enzymes of glycolysis. Phosphohexose isomerase is a stabe enzyme and is relatively easily estimated. 


\section{MATERIALS}

The sources of the materials for this study were samples from women attending the gynaecological departments of the Bedford General Hospital and the Luton and Dunstable Hospital.

\section{METHODS}

The samples were collected and prepared in a similar manner to that of Bonham and Gibbs (1962). The assay of 6-phosphogluconate dehydrogenase used was that of Glock and Mclean (1953). Phosphohexose isomerase assay used was that of Bodansky (1954). The extract of vaginal fluid was diluted one in five with normal saline $(0.2 \mathrm{ml}$. to 1.0$)$ before the assay.

In this assay the micrograms of fructose-6-phosphate liberated are estimated by a resorcinal reaction and the colour developed compared with a standard curve.

CALCUlation The micrograms of fructose liberated are divided by the incubation time of 30 minutes and the molecular weight to give the $\mu$ moles liberated per minute. The milligrams of vaginal fluid in the reaction mixture is equal to milligrams per $0.1 \mathrm{ml}$. in the original dilution, since $0.2 \mathrm{ml}$. is diluted to $1.0 \mathrm{ml}$. with normal saline and then $0.5 \mathrm{ml}$. used for the reaction. Thus $\mu$ moles liberated per gram per minute

$$
=\frac{\mu \text { moles per minute }}{\mathrm{mg} \cdot \text { per } 0 \cdot 1 \mathrm{ml}} \times 1,000
$$

\section{RESULTS}

NORMAL WOMEN The phosphohexose isomerase content of vaginal fluid was studied in 38 apparently normal women. The results are shown in Figures 1 and 2. From these figures it can be seen that 31 $(80.9 \%)$ of samples gave activities of less than 3 $\mu$ moles fructose formed per minute per gram dry weight. It was felt that this level of activity should be taken as the upper limit for normal women.

In Fig. 2 the activities on these cases are compared with the activities of 6-phosphogluconate dehydrogenase.

Of the seven cases with phosphohexose isomerase levels greater than $3 \mu$ moles per minute per gram, four samples had no detectable 6-phosphogluconate dehydrogenase activity in the samples, while two samples had 6-phosphogluconate dehydrogenase activities of less than 80 units per gram. In the remaining case the 6-phosphogluconate dehydrogenase activity was greater than 80 units per gram dry weight. Of these 38 samples only one had an elevated 6-phosphogluconate dehydrogenase; 29 had no detectable 6-phosphogluconate dehydrogenase activity.

BENIGN GYNAECOLOGICAL LESIONS One hundred and six samples were obtained from women with benign
Percentoge of cases

$\begin{array}{llllllll}10.8 & 29.7 & 27 & 13.5 & 5.4 & 2.7 & 10.8\end{array}$

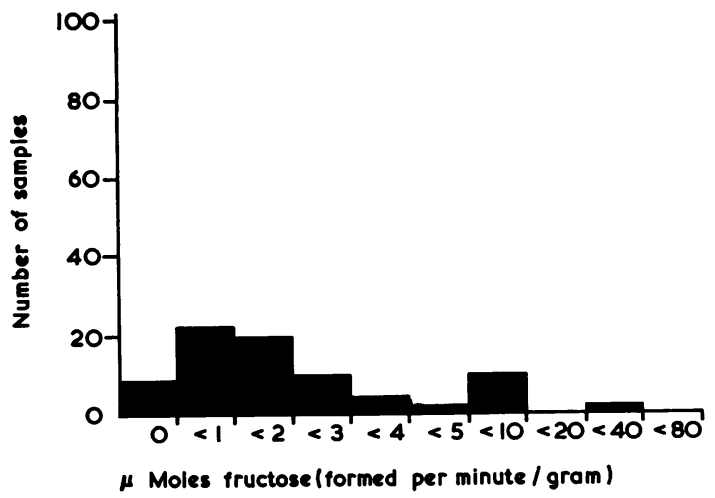

FIG. 1. Phosphohexose isomerase activity in normal women.

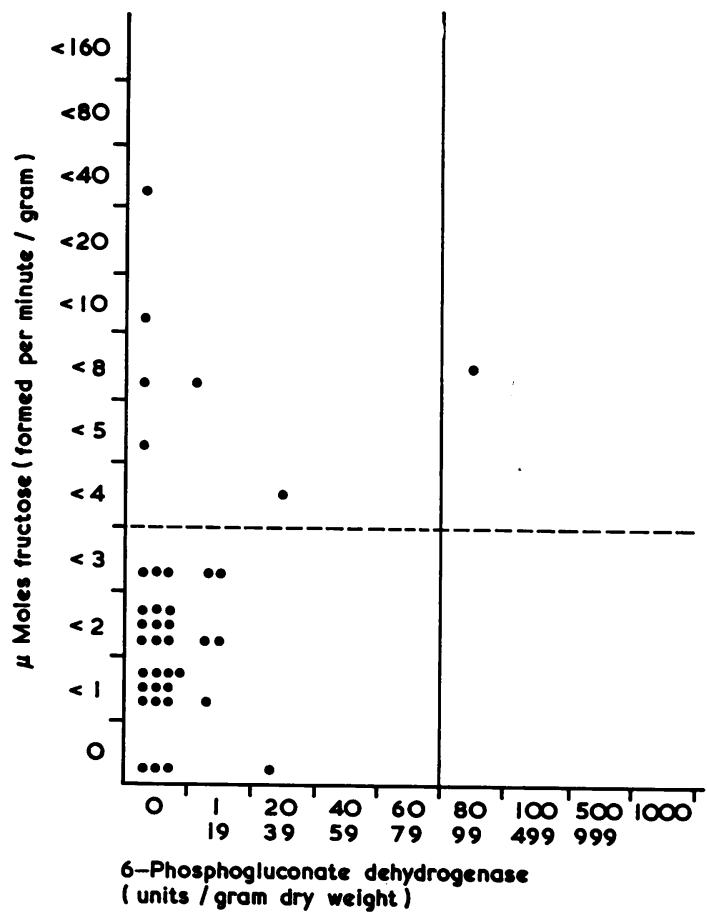

FIG. 2. Phosphohexose isomerase activity in normal women.

gynaecological lesions. The results are shown in Figures 3 and 4. Twenty-eight $(20.9 \%)$ of the 106 cases had levels of phosphohexose isomerase less than $3 \mu$ moles per minute per gram. In Fig. 4 the 
Percentoge of cases

$\begin{array}{lllllllllll}5.4 & 0.7 & 8.9 & 5.9 & 5.1 & 5.9 & 19.9 & 28.5 & 14 & 3.7 & 2.9\end{array}$

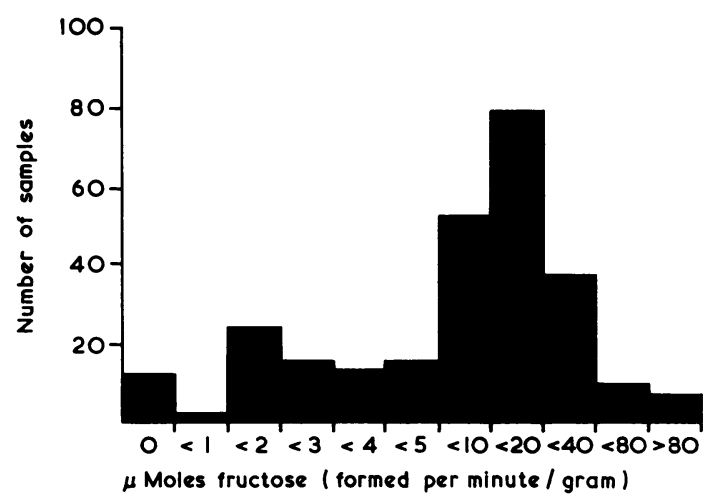

FIG. 3 .

FIG. 3. Phosphohexose isomerase activity in women with gynaecological lesions.

FIG. 4. Phosphohexose isomerase activity in samples from cases with gynaecological lesions.

results are compared with 6-phosphogluconate dehydrogenase activities.

In this group 84 samples had phosphohexose isomerase levels of more than $3 \mu$ moles per minute per gram dry weight. Forty of these samples were associated with elevated levels of 6-phosphogluconate dehydrogenase. There were five samples with elevated 6-phosphogluconate dehydrogenase levels which did not have elevated levels of phosphohexose isomerase. The phosphohexose isomerase is very much more often elevated than the 6-phosphogluconate dehydrogenase.

If there is an elevated 6-phosphogluconate

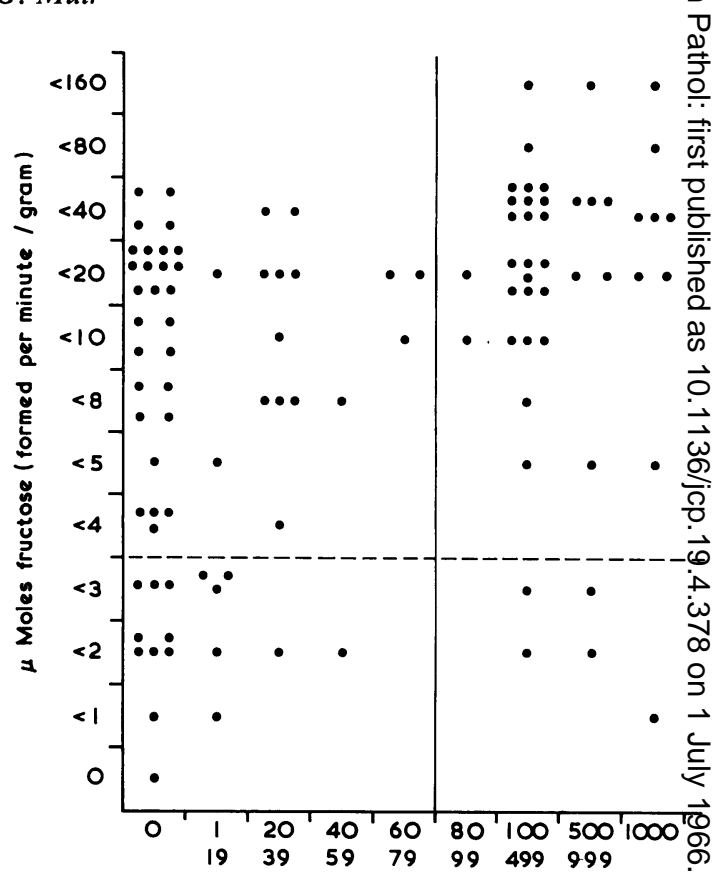

FIG. 4. ( units / gram dry weight

dehydrogenase activity it is likely that phosph\%ّ hexose isomerase levels will also be elevated. Tables I and II the level of phosphohexose isomera君 is compared with the overall cytological pattern. $\mathrm{\nexists t}$ can be seen that the presence of leucocytes erythrocytes causes a marked increase in the level $\overline{\mathrm{g} f}$ phosphohexose isomerase, both in pre- and pos menopausal women; similar results are shown wif other cytological abnormalities. In the comparison with the results with 6-phosphogluconate dehydrogenase it would appear that this enzyme is not affected to so great a degree by the presence of leucocytes or erythrocytes.

TABLE I

RESULT IN PRE-MENOPAUSAL WOMEN

Cytological Pattern

Phosphohexose Isomerase

( $\mu$ moles/min./g.)

\begin{tabular}{|c|c|c|c|c|c|c|c|c|}
\hline & \multicolumn{5}{|c|}{$(\mu$ moles $/$ min. $/ g)}$. & \multicolumn{3}{|c|}{ (units per g.) } \\
\hline & Nil & $<3$ & $<8$ & $<20$ & $>20$ & Nil & $<80$ & $>80$ \\
\hline Excessive leucocytes or erythrocytes & - & $\begin{array}{c}7 \\
15 \%\end{array}$ & $\begin{array}{c}7 \\
15 \%\end{array}$ & $\begin{array}{l}17 \\
38 \%\end{array}$ & $\begin{array}{l}14 \\
32 \%\end{array}$ & $\begin{array}{l}13 \\
29 \%\end{array}$ & $\begin{array}{l}8 \\
18 \%\end{array}$ & $\begin{array}{l}24 \\
53 \%\end{array}$ \\
\hline Increased parabasal cells & 一 & 1 & - & 一 & 3 & 1 & - & 3 \\
\hline Other cytological patterns ${ }^{1}$ & - & 4 & 2 & 6 & 3 & 4 & 3 & 8 \\
\hline Normal patterns ${ }^{2}$ & $\begin{array}{c}5 \\
54 \%\end{array}$ & $\begin{array}{l}25 \\
54 \%\end{array}$ & $\begin{array}{l}10 \\
18 \%\end{array}$ & $\begin{array}{l}12 \\
21 \%\end{array}$ & $\begin{array}{l}3 \\
7 \%\end{array}$ & $\begin{array}{l}36 \\
65 \%\end{array}$ & $\begin{array}{l}11 \\
20 \%\end{array}$ & $\begin{array}{c}8 \\
15 \%\end{array}$ \\
\hline
\end{tabular}

1The other cytological patterns include dysplasias, increased endocervical cells and low oestrogen patterns.

${ }^{2}$ Those in the normal pattern include patients with gynaecological lesions, but a normal pattern as distinct from the normal women who hay neither. 
TABLE II

RESULTS IN POST-MENOPAUSAL WOMEN

Cytological Pattern

Phosphohexose Isomerase

(umoles/min./g.)

6-Phosphogluconate Dehydrogenase

Nil

Excessive leucocytes or erythrocytes

- $11 \%$

Increased parabasal cells

Other cytological patterns

Normal patterns

VARIATIONS WITH THE MENSTRUAL CYCLE Since there were only 38 completely normal women in this series it was felt that this made too small a group to study the variations with the cycle. In order to get a larger group the normal pre-menopausal women have been grouped with those pre-menopausal women with gynaecological lesions. The menstrual cycle was divided into four-day periods and the percentage of cases with levels greater than $3 \mu$ moles per minute per gram of vaginal debris calculated. The results are given in Figure 5. There is an expectedly high incidence of elevated phosphohexose isomerase during menstruation. There is a peak between the 12 th and 16th days during the ovulatory phase, which then falls between days 16 and 20 , rising again during days 20 to 24 until the end of the cycle.

Table III shows the results in post-menopausal women; both normal women and cases with benign gynaecological lesions are included. There is obviously an increase in the incidence of elevated enzyme levels in this group when compared with pre-menopausal women. The increased occurrence of elevated levels becomes more marked when they are compared with the apparently normal premenopausal women. In Fig. 6 the results for the two enzymes are compared; it is obvious that the phosphohexose isomerase level is more often elevated than the 6-phosphogluconate dehydrogenase.

\section{RESULTS IN MALIGNANCY}

CARCINOMA IN SITU In Table IV the results in six cases of carcinoma in situ are shown: estimation of

\section{TABLE III}

EFFECT OF THE MENOPAUSE ON THE VALUE OF PHOSPHOHEXOSE ISOMERASE

\begin{tabular}{llr}
$\begin{array}{l}\text { Phosphohexose Isomerase } \\
\text { (umoles/min./g.) }\end{array}$ & $\begin{array}{l}\text { No. } \\
\text { Premenopausal }\end{array}$ & $\begin{array}{l}\text { No. } \\
\text { Postmenopausal }\end{array}$ \\
\hline Less than 3 & $43(36.0 \%)$ & $13(29 \cdot 3 \%)$ \\
Less than 8 & $24(19 \cdot 8 \%)$ & $7(15.9 \%)$ \\
Less than 20 & $34(28.0 \%)$ & $16(36.4 \%)$ \\
More than 20 & $20(16.2 \%)$ & $8(18.2 \%)$
\end{tabular}


6-phosphogluconate dehydrogenase detected two out of six whereas that of phosphohexose isomerase detected all the cases.

\begin{tabular}{lcc}
\multicolumn{3}{c}{ T A B LE IV } \\
CARCINOMA IN SITU \\
Case No. & $\begin{array}{l}\text { 6-Phosphogluconate } \\
\text { Dehydrogenase } \\
\text { (units per g.) }\end{array}$ & $\begin{array}{l}\text { Phosphohexose } \\
\text { Isomerase } \\
\text { (umoles/min./g.) }\end{array}$ \\
\hline 1 & 153 & $10 \cdot 7$ \\
2 & nil & 6.6 \\
3 & nil & 12.7 \\
4 & nil & 5.5 \\
5 & 38.3 & $6 \cdot 72$ \\
6 & 1050 & 5.5
\end{tabular}

In Table $\mathrm{V}$ the results of the 13 cases of invasive carcinoma of the cervix are shown. There were 17 samples taken from these cases; of these, four were not detected by estimating 6-phosphogluconate dehydrogenase, while all but one was detected by phosphohexose isomerase.

TABLE V

CARCINOMA OF THE CERVIX

\begin{tabular}{ccc} 
Case No. & $\begin{array}{l}\text { 6-Phosphogluconate } \\
\text { Dehydrogenase } \\
\text { (units per g.) }\end{array}$ & $\begin{array}{l}\text { Phosphohexose } \\
\text { Isomerase } \\
\text { (umoles/min./g.) }\end{array}$ \\
\hline 1 & 2,042 & $10 \cdot 7$ \\
& 1,280 & $9 \cdot 3$ \\
2 & 565 & $10 \cdot 2$ \\
3 & 1,830 & $9 \cdot 8$ \\
& 43 & $3 \cdot 5$ \\
4 & 201 & $1 \cdot 1$ \\
5 & $28 \cdot 8$ & $11 \cdot 5$ \\
6 & 2,480 & $4 \cdot 6$ \\
& 537 & $19 \cdot 0$ \\
7 & 24 & $3 \cdot 8$ \\
8 & 207 & $11 \cdot 5$ \\
9 & 825 & $17 \cdot 5$ \\
10 & $16 \cdot 6$ & $27 \cdot 4$ \\
11 & 2,250 & $34 \cdot 4$ \\
12 & 288 & $30 \cdot 7$ \\
13 & 345 & $15 \cdot 8$ \\
& 443 & $42 \cdot 6$
\end{tabular}

In Table VI, six cases of carcinoma of the body are shown, and seven of carcinoma of the ovary. These were all detected by estimating 6-phosphogluconate dehydrogenase, and all except two of the ovarian carcinomas, detected by phosphohexose isomerase. In general the phosphohexose isomerase is the more reliable enzyme; ovarian carcinoma is the only exception to that rule. Once again, it is apparent that the levels of the two enzymes do not correlate with each other, but it is a fair generalization that if the level of 6-phosphogluconate dehydrogenase is raised, then that of phosphohexose isomerase will also be raised.

\section{DISCUSSION}

Unlike 6-phosphogluconate dehydrogenase, phos-
TABLE VI

6-Phosphogluconate Dehydrogenase (units per $\mathrm{g}$.)

Carcinoma of the body

398

404

355

355
736
990

990

282

Phosphohexose Isomerase (umoles/min./g.)

Ovarian carcinoma

$$
\begin{array}{r}
958 \\
341 \\
\text { nil } \\
1,459 \\
\text { nil }
\end{array}
$$

$19 \cdot 4$

259

$18 \cdot 6$

$19 \cdot 1$

$5 \cdot 74$

$22 \cdot 8$

$1 \cdot 12$

$14 \cdot 0$

6.47

$4 \cdot 14$

0.79

phohexose isomerase is normally present in the vaginal fluid, but not usually in amounts greater than $3 \mu$ moles per minute per gram in normal women. is obvious that different factors regulate the level of phosphohexose isomerase in the vaginal fluid to those which regulate the 6-phosphogluconate dehydrogenase activities. In normal women they apper to be independent of each other, though if the 6-phosphogluconate dehydrogenase activity is ig creased, the phosphohexose isomerase is also increased. The reverse does not apply. It is increased to a considerable degree in any women with a lesion of the gynaecological tract, the incidence of activitis more than $3 \mu$ moles per minute per gram rising fro $20 \%$ to about $62 \%$ in these cases. From Fig. 5 it $\$$ s obvious that phosphohexose isomerase is profound $\overrightarrow{\mathrm{By}}$ influenced by the cytological pattern in the vagina. In pre-menopausal women with gynaecological lesions but no cytological abnormality, $46 \%$ had phosphohexose isomerase activities of more than $3 \mu$ moles per minute per gram. If there is an excess of leucocytes or erythrocytes present, the incidence of samples with activities more than $3 \mu$ moles per minute per gram rises to $85 \%$. A similar change bot not so large occurs with 6-phosphogluconate dehydrogenase. Phosphohexose isomerase, like 6-phosphogluconate dehydrogenase, seems to measureóa reaction of the vaginal epithelium to an irritant.

Both 6-phosphogluconate dehydrogenase afid phosphohexose isomerase activities in the vagingl fluid increase after the menopause. The variation with the menstrual cycle is different from that with 6-phosphogluconate dehydrogenase, in that there a rise during the ovulatory period with a fall durif days 16 to 20 and then a maintained rise during dofs 20 to 28. 6-Phosphogluconate dehydrogenase appears to be at its lowest level from the ovulatôy period to the day immediately preceding menstresttion (results to be published).

In malignancy the results with phosphohexosse isomerase are very encouraging. No cases of carcin- 
oma in situ were missed, only one of invasive carcinoma, and no case of carcinoma of the body of the uterus. The results are considerably better than those obtained with 6-phosphogluconate dehydrogenase. Estimation of phosphohexose isomerase does not appear to detect ovarian carcinoma quite so well as 6-phosphogluconate dehydrogenase. This is probably because the growth does not abut on to the vagina. This raises the interesting point as to the mechanism of the elevated level of 6-phosphogluconate dehydrogenase in ovarian carcinoma.

On first impressions such an enzyme would appear to have no potential as a diagnostic test. On the other hand there is good evidence that this enzyme has missed no cases of carcinoma in situ. It is unlikely that in the near future an enzyme will be found which is specific for carcinoma and sufficiently sensitive to be useful as a diagnostic test for carcinoma in situ. Thus at the moment it is unlikely that an enzymological test will replace vaginal and cervical cytology.

If, on the other hand, a suitable screen test is sought for carcinoma in situ, phosphohexose isomerase may have a place. It is an enzyme which any hospital with a standard autoanalyser could assay and it does not require any additional apparatus. If such an enzyme were used in a well women's clinic, assuming they were all apparently clinically normal, $20 \%$ of the smears would have to be inspected, and again the cytologist would have the assurance that there would probably be some pathology there. In Measday's experience (1962) the incidence of gynaecological abnormality in a well women's clinic would be between 30 and $36 \%$. Using this figure as a basis, the number of smears which would be eliminated can be calculated. Of 100 women attending the clinic, 36 would have some minor gynaecological abnormality. Eight per cent of these 36 would have raised enzyme levels, thus 29 smears would have to be inspected. Of the remaining 64 , $20 \%$ would give raised enzyme levels, and a further 13 smears would have to be inspected. Thus in a well women's clinic 42 cases would have to be examined after the preliminary screening with the phosphohexose isomerase. The cytologist would have the confidence that of the cases he looked at, all would have a lesion; also that of the smears discarded, he would not miss a case of carcinoma in situ. This is a useful aspect of enzymology, and is a possibility which should be followed up on a large scale; the simplicity of automation would make a large-scale trial relatively easy.

\section{REFERENCES}

Bell, J. L., and Egerton, M. E. (1965). J. Obstet. Gynaec. Brit. Cwlth, $72,603$.

Bodansky, O. (1965). Cancer(Philad.), 7, 1191.

Bonham, D. G., and Gibbs, D. F. (1962). Brit. med. J., 2, 823.

Fishman, W. H., Green, S., Homburger, F., Kasdon, S. C., Nieburgs, H. E., McInnis, G., and Pund, E. R. (1954). Cancer (Philad.), 7, 729.

Glock, G. E., and Mclean, P. (1963). Biochem. J., 55, 400.

Jegatheesan, K. A. (1959). Ph.D. Thesis, University of London.

, and Joplin, G. F. (1962). Brit. med. J., 1, 831.

Joplin, G. F., and Jegatheesan, K. A. (1962). Ibid., 1, 827.

Kasdon, S. C., Homburger, F., Yorshis, E., and Fishman, W. H. (1953). Surg. Gynec. Obstet., 97, 579.

Lawson, J. G. (1959). J. Obstet. Gynaec. Brit. Emp., 66, 946. , and Watkins, D. K. (1965). J. Obstet. Gynaec. Brit. Cwlth, $72,1$.

Measday, B. (1926). Lancet, 2, 395.

Morris, H. P. (1963). Progr. exp. Tumor Res. (Basel), 3, 370.

Muir, G. G., Canti, G., and Williams, D. (1964). Brit. med. J., 2, 1563.

Weber, and Fawcett, A. N. (1965). Brit. J. Cancer, 19, 274. 